\title{
MODE OF ACTION OF VIRECHAN KARMA
}

\section{Chintamani D. Patil ${ }^{1}$, Amol A. Patil ${ }^{2}$}

1. PG Scholar, Panchakarma Dept.

2. Guide and Asso. Professor, Panchakarma Dept. LKRAMC, Gadhinglaj.

*Corresponding author: Email Id - chintspati186@gmail.com; Phone no. 8552888796.

\section{ABSTRACT:}

Virechana Karma is the process of expelling doshas through Adhobhaga i.e. Guda. It is the detoxifying procedure that should be performed only after doing snehan (both internally and externally) and swedan. Virechan is indicated in multiple conditions like Pitta Pradhana Vyadhi's like Pandu and Kamala, Rakta Pradoshaja Vyadhi like Kustha, Visarpa and Raktapitta , Amlapitta, Prameho: Amavata, Hridayaroga, Pakshaghatd Sthaulya. In this article, we are describing Mode of action of Virechan karma according to Ayurveda and Modern Science. We will see how modern science is helpful in understanding the facts related to Virechan karma. We will see the importance and need of understanding mode of action in this article.

KEY WORDS: - Mode of Action, Virechan, Purgation.

\section{INTRODUCTION :-}

Virechana Karma is the process of expelling doshas through Adhobhaga i.e. Guda ${ }^{[1]}$.

Amashaya is the specific seat of Pitta dosha, even though virechan is the specific therapy for morbid pitta dosha, it also can be used for elimination of kapha dosha. It is the most widely used detoxification procedure especially for Pittaj disorders. Virechan is the best therapeutical procedure for Pitta Dosha ${ }^{[2,3]}$.

It is also useful in disorders in which pitta is associated with vata or kapaha. [4]

It is indicated in multiple conditions like Pitta Pradhana Vyadhi's like Pandu and Kamala, Rakta Pradoshaja Vyadhi like Kustha, Visarpa and Raktapitta, Amlapitta, Prameha, Amavata, Hridayaroga, Pakshaghata, Sthaulya.

It is also used as a preparatory procedure before Rasayan and Vajikaran.

Different Virechan kalpas like Trivrut, Danti Haritaki,etc. are mentioned in Charak Samhita.

In Sushrut Samhita, Asthng Hruday and Sharangdhar Samhita, there is elaborate explaination of Virechanopayogi dravyas and Virechan vidhi.

AIM -

To do critical analysis of Mode of action of Virechan karma.

\section{OBJECTIVES -}

1. To study action of Virechan according to Ayurveda.

2. To study action of Virechan according to Modern Science. 
3. To Correlate the action of Virechan in Ayurveda and Modern Science.

\section{MATERIALS AND METHODS:-}

Type of Study - Literary Research.

\section{Virechana Drugs According To Their Mode Of Action :-}

Acharya Sharangdhara has classified Virechan drugs into 4 types on the basis of action, potency of drug and consistency of stool.

- Anulomana ${ }^{[5]}$ - The drugs that excrete the Malas downwords after digesting it and breaking its bandha are known as Anulomana. eg. Haritaki

- Sramsana ${ }^{[6]}$ - The drugs which bring the semi-digested and sticky Mala without doing its digestion is known as Sransana. eg. Aragvadha.

- Bhedana [7] - The Drugs whic disintegrate the Abaddh (unformed) or Baddha (formed) ơ Pindita (dried fecal mass) forms of Mala by penetrating into it and then evacuating is known as Bhedana eg. Katuki. Acharya Charaka has described a group of drug named as Bhedaniya Mahakashay ${ }^{[8]}$. This includes Suvaha (Trivrit), Arka, Urubuka (Eranda), Agnimukhi (Kalihari), Chitra (Danti), Chitraka, Chirabilva, Sankhini, Shakuladani (Katuki) and Svarnakshiri.

- Rechana ${ }^{[9]}$ - The drugs which eliminate Pakvam (digested) and Apakvam (undigested) Malas or Doshas by making it loose is known as Rechana. eg. Trivrut.

\section{Virechan Dravya :-}

- According to Charak - Shyama Trivrut, Chaturangula, Tilvak,
Mahavriksha, Saptala-Sankhini, Danti-Dravanti. ${ }^{[10]}$

- According to Sushrut - Trivrut, Shayama, Danti, Dravanti,Saptala, Sankhini, Vishanika, Gavakshi, Chagalantri, Snuk, Svarnakshiri, Chitrak, Kinihi, Kush, Kasa, Tilvak, Kmpillak, Ramyaka, Patala, Puga, Haritaki, Amalaki, Bibhitaki, Nilini, Chaturangula, Eranda, Putika, Mahavriksha, Saptacchada, Arka, Jyotishmati. ${ }^{[11]}$

- According to Vagbhat - Trivrut, Kumbha, Triphala, Gavakshi, Snuhi, Sankhini, Nilini, Tilvaka, Aragvadha, Kampillaka, Hemadugdha, Dugdha, Mutra. ${ }^{[12]}$

- Virechanopaga Mahakashay These are drugs which helps in smooth Virechan or which synergies the action of Virechan Dravya. Drugs described are Draksha, Kasmarya, Parushaka, Abhaya, Amalaki, Bibhitaki, Kuvala, Badara, Karkandhu and Pilu. ${ }^{[13]}$

\section{VIRECHAN KARMUKATVA :- MODE OF ACTION OF VIRECHAN (AYURVEDIC VIEW)}

Action of Virechan Karma is divided in the following two ways. ${ }^{[14]}$

1. Systemic - by which it brings down the morbid dosha, particularly Pitta from shakha to Koshtha.

2. Local evacuant - which is concerned with the evacuation of these dosha in form of Mala from the gut by Adhobhagahara property.

Virechana drugs are having Ushna, Teekshna, Sukshma, Vyavayee, Vikashi properties and Adhobhagahar Prabhav. $[15,16]$

Virechan dravya gets absorbed by its Veerya, it reaches to Hridaya, then the Dasha Dhamani and thereafter it reaches 
to macro and micro-channels of the body. i.e. sukshmati sukshma srotas.

Ushna Guna has Agneya property and hence the dosha sanghata is liquified (Vishyandana). Hence it facilitates movement of morbid Doshas towards Kostha.

Due to Teekshna Guna, mala and doshas breaks up in micro form that helps in quick excretion.

Due to Pranava bhava of Sukshma Guna, it opens micro channels and makes the Doshas to move towards Kostha.

Due to Vyavayee Guna these drugs spreads quickly throughout the body and starts their action before its digestion.
Vikashi Guna of drugs causes loosening of the bond between Dosha and Dhatu causing Dhatu Shaithilya.

From all these properties Doshas are driven to Kostha. These drugs consist of Prithvi and Jala Mahabhootas which are heavy in nature and adhobhagahar Prabhav which helps in expulsion of Dosha from Adhobhaga (anal route). ${ }^{[17]}$

From the above description a hypothesis can be postulated that due to the Veerya of the Virechan drugs softening, disintegration, liquification of endogenic metabolic products occurs, and then brought to the koshtha for elimination. ${ }^{[18]}$

\section{Flow Chart of Virechan Karmukatwa :-}

Virechan drugs (Ushna, Teekshna, Sukshma, Vyavayee, Vikashi properties)<smiles>[CH]=C</smiles>

Due to their Veerya, Move to Hridaya

From there, through Dasha Qhamani (Vyavayee),
to macro and micro-channels of the body (Anutva property)

reaches to macro and micro-channels of the body (Anutva
Act over the vitiated complexes in the body

With 'Agneya property'- liquefy the complexes (Vishyandana)

lु

With 'Teekshna property' -break them down into several particles

l了

Liquefied matter then glides through various unctuous channels towards

Shakha to kostha (Pravana bhava of sukshma guna)

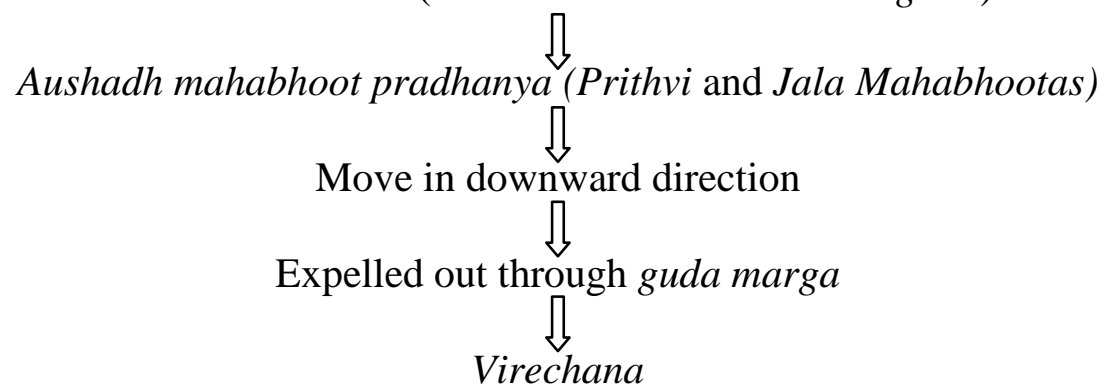

\footnotetext{
Physiology Of Virechan Karma (The Defaecation Reflex) ${ }^{[19]}$ :-
}

- Mass peristaltic movements push faecal material from the sigmoid colon into the rectum. 
- The resulting distension of the rectal wall stimulates stretch receptors, which initiates a defecation reflex that empties the rectum.

- The defecation reflex occurs as follows :- In response to distension of the rectal wall, the receptors send sensory nerve impulses to the sacral spinal cord. Motor impulses from the cord travel along parasympathetic nerves back to the descending colon, sigmoid colon, rectum and anus.

- The resulting contractions of the longitudinal rectal muscles shorten the rectum, thereby increasing the pressure within it.

- This pressure, along with voluntary contractions of the diaphragm and abdominal muscles, plus parasympathetic stimulation, opens the internal anal sphincter.

- The external anal sphincter voluntarily controlled. If it voluntarily relaxed, defecation occurs and the faeces are expelled through the anus.

\section{MECHANISM OF ACTION (MODERN VIEW)}

The virechan drug acts in pachyamana awastha, means in the digestion state. So it starts its action in stomach, small intestine. These drugs act by the mechanism of osmotic pressure, mysenteric plexus stimulation, receptor activation causes local irritation, etc. Hence it is not possible to explain in a single theory. ${ }^{[20]}$

All the purgatives increase the water content of faeces by ${ }^{[21]}$;-

1. A hydrophilic or osmotic action, retaining water \& electrolytes in the intestinal lumen - increase volume of colonic content and make it easily propelled.
2. Acting on intestinal mucosa to decrease net absorption of water and electrolyte, intestinal transit is enhanced indirectly by the fluid bulk.

3. Increasing propulsive activity as primary action-allowing less time for absorption of salt and water as a secondary effect.

4. Certain purgatives do increase motility through an action on the mesenteric plexuses.

Stimulant Purgatives :- These are potent and irritate the intestinal mucosa and by which they stimulates motor activity. Few of them increase motility by acting on mesenteric plexuses, accumulation of water and electrolytes in the lumen by altering absorptive and secretary activity of the mucosal cell is an important action. They inhibit $\mathrm{Na}+\mathrm{K}+$ ATpase at the basolateral membrane of villous cells transport of $\mathrm{Na}+$ and accompanying water into the interstitium is reduced. Secretion enhanced by activation of cyclic AMP in crypt cells and by increased Prostaglandin synthesis. ${ }^{[22]}$

\section{MODE OF ACTION (MODERN VIEW) ${ }^{\text {[23] }}$}

Local action:- Virechan dravya are mild irritant to the stomach and the intestinal mucosa to cause inflammation. Hence hyperaemia occurs due to arteriolar dilatation and capillary dilatation. Exudation of protein rich fluid through the vessel wall in the intestinal tissue helps in dilution of toxins. ${ }^{[24]}$

\section{Action on Nerves :-}

The process of Virechan is regulated and controlled by a special centre situated near Medulla Oblongata in the brain. ${ }^{[25]}$. This centre is close to respiratory and vomiting centre. Virechan drugs acts on nerves, hormones, liver and crypts of lieberkuhn and they have irritating effect on 
defecation Centre in Medulla oblongata. The vagus nerve stimulate pancreas \& liver to produce secretions. Bile is secreted due to contraction of Gall Bladder due to irritation \& stimulation of vagus nerve. Bruner's gland are stimulated which secretes mucus ${ }^{[26]}$. Due to increased peristalsis, Sacral \& lumber plexus are irritated, ileo-caecal\& anal sphincters are relaxed\& these secretions are excreted out. - The act of purgation is also controlled and regulated by local reflex action of the concerned body parts. Defecation center is situated in sacral segments (center) of the spinal cord ${ }^{[27]}$. During the act of defecation the respiration is arrested momentarily, diaphragm is activated and it presses transverse colon. Simultaneously the accessory muscles of the abdomen are also activated and they also help in propelling the faecal matter towards anus. Faecal matter when reaches to intestine, stimulates local nerve plexuses and then the enforced peristalsis further helps in expelling contents of intestine toward rectum and finally to anal canal. When th voluntary or involuntary act of defecation starts, the ultimate result is evacuation of bowels.

\section{Hormonal Action ${ }^{[28]}$ :-}

Virechan drugs causes irritation in intestinal mucosa, thereby leading to excessive secretions from intestinal mucosa like hepatocrinin, secretin and cholecystokinin. This leades to irritation and stimulation of vagus nerve. Vagus nerve causes irritation of Liver and
Pancreas which causes increase small intestinal secretions which adds to irritation of mucosa. Whenever a segment of large intestine irritates, then mucosa secretes large quantities of water and electrolytes in addition to alkaline mucus. This leads to dilution of irritating factors and cause rapid movements of the faeces towards anus. The mechanism by which marked secretion of watery fluid by crypts of Lieberkuhn occur is unknown. However, two active secretory processes occur. Active secretion of chloride ions (into the crypts) and bicarbonate ions. The secretion of chloride ions causes electrical transfer of sodium ions through the membrane. Finally all these cause osmotic movement of water and hence fluidity in the purgation occurs.

\section{Elimination of Bile :-}

Hepatocrinin stimulates liver to secrete bile $^{[29]}$. Cholecystokinin hormone causes contraction of gall bladder ${ }^{[30]}$. This causes ncreased secretion of digestive enzymes from pancreas. Gall Bladder is also stimulated by Acetylcholine. Due to the relaxant action of sphincter of oddi, bile enters into duodenum which is eliminated at the time of purgation ${ }^{[31]}$. This bile contains solids, bile salts, bile pigments, bile acids, cholesterol, lecithin, water, sodium, potassium, bicarbonate ions, fats and fatty acids which are eliminated out. Liver excretes cholesterol, bile pigments, heavy metals, (like lead, arsenic and bismuth), toxins, bacteria and virus (like that of yellow fever) through bile ${ }^{[32]}$.

\section{Flow chart of Mode of Action of Virechan (Modern View) :-}


Virechana drug

Cause Irritation in

Leading to excessive secretion from Intestinal mucosa and vasodilatation

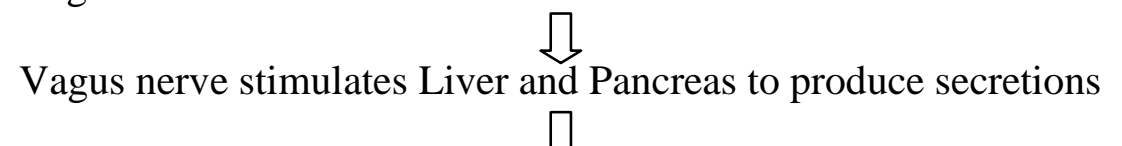

Cholecystokinin hormone causes contraction of gall bladder<smiles>[C+]1=CC=C1</smiles>

Increased secretion of digestive enzymes from pancreas

ఐ

Due to relaxant action of sphincter of oddi, bile enters into duodenum.

$\prod$

Liver excretes cholesterol, bile pigments, heavy metals, (like lead, arsenic and bismuth),

toxins, bacteria and virus (like that of yellow fever) through bile

凸

Toxins present in gut lumen along with secretion of electrolyte and fluid from crypt of lieberkuhn in distal ileum and colon

$\prod$

Expulsion of toxins + fluid + electrolyte through anal route

\begin{abstract}
ANALYSIS AND DISCUSSION:-
Virechan drug acts in pachyaman awastha, means in the digestion state. So starts its action in stomach, small intestine. These drugs act by the

ions, fats and fatty acids which are liminated out can be called as Pitta. Liver xcretes cholesterol, bile pigments, heavy metals, (like lead, arsenic and bismuth), toxins, bacteria and virus (like that of yellow fever) through bile.
\end{abstract} mechanism of osmotic pressure, myenteric plexus stimulation, receptor activation causes local irritation, etc. Virechan drugs acts on nerves, hormones, liver and crypts of lieberkuhn and they have irritating effect on defecation centre in medulla oblongata. Virechan drugs causes irritation in intestinal mucosa, thereby leading to excessive secretions from intestinal mucosa like hepatocrinin, secretin and cholecystokinin. The vagus nerve stimulate pancreas and liver to produce secretions. Cholecystokinin hormone causes contraction of gall bladder. This causes increased secretion of digestive enzymes from pancreas. Due to relaxant action of sphincter of oddi, bile enters into duodenum.

This bile contains solids, bile salts, bile pigments, bile acids, cholesterol, lecithin, water, sodium, potassium, bicarbonate
Bruner's gland are stimulated which secretes mucus. Whenever a segment of large intestine irritates, then mucosa secretes large quantities of water and electrolytes in addition to alkaline mucus. This leads to dilution of irritating factors and cause rapid movements of the faeces towards anus. The mechanism by which marked secretion of watery fluid by crypts of Lieberkuhn occur is unknown. However, two active secretory processes occur. Active secretion of chloride ions (into the crypts) and bicarbonate ions. The secretion of chloride ions causes electrical transfer of sodium ions through the membrane. Finally all these cause osmotic movement of water and hence fluidity in the purgation occurs. 
Virechana drugs are having Ushna, Teekshna, Sukshma, Vyavayee, Vikashi properties and Adhobhagahar Prabhav. Due to the Veerya and above properties of the Virechan drugs, there is softening, disintegration, liquification of endogenic metabolic products, and are brought to the koshtha for elimination.

In this article, the emphasis is made on the mode of action of Virechan karma from both Ayurvedic and Modern point of view.

\section{CONCLUSION:-}

The Mode of action of Virechan karma is revealed by Ushna, Teekshna, Sukshma, Vyavayee, Vikashi properties and Adhobhagahar Prabhav of virechan drugs. Liver excretes cholesterol, bile pigments, heavy metals, (like lead, arsenic and bismuth), toxins, bacteria and virus (like that of yellow fever) through bile. Bile can be called as Pitta according to Ayurveda. So Virechan is the best purificatory procedure especially for Pittaj disorders because of its simplicity eliminating doshas in more quantity wit less stress and having lesser complication compared to Vaman.

\section{REFERENCES :-}

1. Dr. Bramhanand Tripathi,Madan kalpadhyay, Charak Samhita of Agnivesh, Kalpasthan, Volume 2, chapter 1, verse no.4, edition 6 , Varanasi, Chaukhambha Surabharati Prakashan,1999, page 1072.

2. Dr.

Bramhanand

Tripathi,Yanjapurusheey adhyay, Charak Samhita of Agnivesh, Sutrasthan, Volume 1, chapter 25, verse no.40, edition 6, Varanasi, Chaukhambha Surabharati Prakashan,1999, page 453-454.

3. Vd.D,P.Gadgil,Vd.Yash Joshi, Vd.Sachin Kulkarni, Aayush kamiya adhyay,Ashtang Hriday Sutrasthan, chapter 1, verse no.25,edition 3, Pune, Mankarnika Publication, 2016, page 27.

4. Dr.

Bramhanand

Tripathi,Maharogadhyay, Charak Samhita of Agnivesh, Sutrasthan, Volume 1, chapter 20, verse no.16, edition 6, Varanasi, Chaukhambha Surabharati Prakashan,1999, page 394.

5. Dr.Smt.

Shailaja

Shrivastava,Deepan paachanadi kathanam, Sharangdhar Samhita, Purva Khand, chapter 4, verse no.4, Reprint edition, Varanasi,

Chaukhambha Orientalia, 2015,page 31.

6. Dr.Smt. Shailaja Shrivastava, Deepan paachanadi kathanam, Sharangdhar Samhita, Purva Khand, chapter 4, verse no.5, Reprint edition,Varanasi, Chaukhambha Orientalia, 2015,page 31 .

7. Dr.Smt. Shailaja Shrivastava, Deepan paachanadi kathanam, Sharangdhar Samhita, Purva Khand, chapter 4, verse no.6, Reprint edition, Varanasi, Chaukhambha Orientalia, 2015,page 31.

8. Dr. Bramhanand Tripathi, Shadvirechanashatashriteey adhyay, Charak Samhita of Agnivesh, Sutrasthan, Volume 1, chapter 4, verse no.4, edition 6 , Varanasi, Chaukhambha Surabharati Prakashan,1999, page 77.

9. Dr.Smt. Shailaja Shrivastava, Deepan paachanadi kathanam, Sharangdhar Samhita, Purva Khand, chapter 4, verse no.7, Reprint edition, Varanasi, Chaukhambha Orientalia, 2015,page 31 .

10. Dr. Bramhanand Tripathi,Madan kalpa adhyay, Charak Samhita of Agnivesh, Kalpasthan, Volume 2, chapter 1, verse no.6, edition 6, Varanasi, 
Surabharati Prakashan,1999, page 1074.

11. Prof. K.R.Srikantha Murthy, Samshodhana samsamaniya adhyay, Illustrated Sushruta Samhita, Sutrasthan, Volume 1, chapter 39, verse no. 4, Reprint Edition, Varanasi, Chaukhambha Orientalia, 2010, page 277.

12. Vd.D,P.Gadgil,Vd.Yash Joshi, Vd.Sachin Kulkarni, Shodhanadi gana sangraha adhyay,Ashtang Hriday Sutrasthan, chapter 15, verse no.2, edition 3, Pune, Mankarnika Publication, 2016, page 253.

13. Dr. Bramhanand Tripathi, Shadvirechanashatashriteey adhyay, Charak Samhita of Agnivesh, Sutrasthan, Volume 1, chapter 4, verse no.24, edition 6 , Varanasi,

Chaukhambha Surabharati Prakashan,1999, page 87.

14. Dr. Vasant Patil,Virechan karma Principles and Practice Panchakarma, chapter 12, edition 5, New Delhi, Chaukhambha Publications, 2015, page 403.

15. Dr. Bramhanand Tripathi, Madan kalpa adhyay, Charak Samhita of Agnivesh, Kalpasthan, Volume 2, chapter 1, verse no.5, edition 6 , Varanasi, Chaukhambha Surabharati Prakashan,1999, page 1072.

16. Prof.

K.R.Srikantha

Murthy, Vaman virechan sadhyopadrava chikitsa, Illustrated Sushruta Samhita, Chikitsasthan, Volume 2, chapter 33, verse no. 33, Reprint Edition, Varanasi, Chaukhambha Orientalia, 2010, page 307.

17. Dr. Bramhanand Tripathi, Aatreya Bhadrakapyeey adhyay, Charak Samhita of Agnivesh, Sutrasthan, Volume 1, chapter 26, verse no.70, edition 6, Varanasi, Chaukhambha
Surabharati Prakashan,1999, page 490.

18. Dr. Vasant Patil,Virechan karma, Principles and Practice of Panchakarma, chapter 12, edition 5, New Delhi, Chaukhambha Publications, 2015, page 404.

19. Gerard Tortora, Sandra Grabowski, Large Intestine, Principles of Anatomy and Physiology, chapter 24, edition 10, John Wiley and Sons, Inc. 2003, page 895.

20. Dr.Manoj Shamkuvar, Virechan adhyay, Panchakarma Sangrah, chapter 5, edition 2,Nagapur, Dhanwantari books and stationers, 2016, page 240.

21. Dr.K D Tripathi, Drugs for Constipation and Diarrhoea, Essentials of Medical Pharmacology, chapter 48, edition 7, New Delhi, Jaypee Brothers Medical Publishers (P) Ltd, 2013, page 672.

22. Dr.K D Tripathi, Drugs for Constipation and Diarrhoea, Essentials of Medical Pharmacology, chapter 48, edition 7, New Delhi, Jaypee Brothers Medical Publishers (P) Ltd, 2013, page 674.

23. Dr.Sharma AK, Kaur Gagandeep, Mode of action of Virechana dravya, Ayush Darpan 'Ayurveda for All', 2014; 131-132.

24. Dr. Vasant Patil, Virechan karma, Principles and Practice of Panchakarma, chapter 12, edition 5, New Delhi, Chaukhambha Publications, 2015, page 405.

25. Vd. Haridas S. Kasture,Virechan vidnyan, Ayurvediya Panchakarma Vidnyan, chapter 5, edition 7, Nagapur, Shree Baidyanath Ayurved Bhawan Pvt Ltd., 2006, page 367.

26. K Sembulingam, Prema Sembulingam, Small Intestine, Essentials of Medical Physiology, chapter 41 , edition 6, New Delhi, 
Jaypee Brothers Medical

Publishers (P) Ltd, 2013, page 262.

27. K Sembulingam, Prema Sembulingam, Movements of Gastrointestinal Tract, Essentials of Medical Physiology, chapter 43 , edition 6, New Delhi, Jaypee Brothers Medical Publishers (P) Ltd, 2013, page 279.

28. Dr. Smita Vinod Zambare, Pharmacokinetics Of Virechana Karma: A Short Review, International Journal of Applied Ayurved Research, 2017, page 1701-1704.

29. Dr.C.C.Chatterjee, Digestive System, Human Physiology, volume 1, chapter 9 , Reprint edition, Kolkatta, Medical Allied Agency, 2003, page 472.
30. K Sembulingam, Prema Sembulingam, Gastrointestinal Hormones, Essentials of Medical Physiology, chapter 44 , edition 6 , New Delhi, Jaypee Brothers Medical Publishers (P) Ltd, 2013, page 284 .

31. Dr.C.C.Chatterjee, Digestive System, Human Physiology, volume 1, chapter 9, Reprint edition, Kolkatta, Medical Allied Agency, 2003, page 477.

32. K Sembulingam, Prema Sembulingam, Liver and Gall Bladder, Essentials of Medical Physiology, chapter 40 , edition 6, New Delhi, Jaypee Brothers Medical Publishers (P) Ltd, 2013, page 255 . 